\title{
Predicting Academic Emotions based on Spiritual Well-being and Life Satisfaction in Students of Shahrekord Girls' Technical and Vocational School
}

\section{Predicción de emociones académicas basadas en el bienestar espiritual y la satisfacción con la vida en estudiantes de la escuela técnica y vocacional para niñas Shahrekord}

\author{
Zahra Ataei \\ Master of Educational Psychology, Department of Psychology, Shahrekord Branch, Islamic \\ Azad University, Shahrekord, Iran. \\ ORCID: 0000-0002-6926-7892 \\ Maryam Chorami* \\ Assistant Professor, Department of Psychology, Shahrekord Branch, Islamic Azad University, \\ Shahrekord, Iran. \\ ORCID: 0000-0003-0227-7970
}


(c) Universidad San Ignacio de Loyola, Vicerrectorado de Investigación, 2021.

Este artículo se distribuye bajo licencia CC BY-NC-ND 4.0 Internacional (http://creativecommons.org/licenses/by-nc$\mathrm{nd} / 4.0 /)$. 


\begin{abstract}
The aim of this study was to predict the academic emotions based on spiritual well-being and life satisfaction in students of Shahrekord Girls' Technical and Vocational School. This was a descriptive correlational study. The study population consisted of all students of Shahrekord Girls' Technical and Vocational School in the 2018-2019 school year. A total of 210 students were selected by the stratified random sampling. The data were collected using the achievement emotions questionnaire (AEQ) (Pekrun, 2005), the spiritual well-being (SWB) scale (Paloutzian and Ellison, 1983) and The Satisfaction With Life Scale (SWLS) (Diener, 1985). Statistical methods and multivariate regression analysis were applied to analyze the data. The results showed that spiritual well-being could predict the academic emotions like pride $(\beta=20 \%)$ and life satisfaction could predict the academic emotions such as enjoyment $(\beta=26 \%)$, anxiety $(\beta=24 \%)$, anger $(\beta=20 \%)$, hopelessness $(B=31 \%)$ and boredom $(\beta=41 \%)$.
\end{abstract}

Keywords: Academic emotions; Spiritual well-being; Life Satisfaction.

\title{
Resumen
}

El objetivo de este estudio fue predecir las emociones académicas basadas en el bienestar espiritual y la satisfacción con la vida en estudiantes de la Escuela Técnica y Vocacional de Niñas Shahrekord. Este fue un estudio descriptivo correlacional. La población de estudio consistió en todos los estudiantes de la Escuela Técnica y Vocacional de Niñas Shahrekord en el año escolar 2018-2019. Un total de 210 estudiantes fueron seleccionados por muestreo aleatorio estratificado. Los datos se recopilaron mediante el cuestionario de emociones de logro (AEQ) (Pekrun, 2005), la escala de bienestar espiritual (SWB) (Paloutzian y Ellison, 1983) y la escala de satisfacción con la vida (SWLS) (Diener, 1985). Se aplicaron métodos estadísticos y análisis de regresión multivariante para analizar los datos. Los resultados mostraron que el bienestar espiritual podría predecir las emociones académicas como el orgullo $(\beta=20 \%)$ y la satisfacción con la vida podría predecir las emociones académicas como el disfrute $(\beta=26 \%)$, la ansiedad $(\beta=24 \%)$, la ira $(\beta=$ $20 \%)$, desesperanza $(\mathrm{B}=31 \%)$ y aburrimiento $(\beta=41 \%)$.

Palabras clave: Emociones académicas; Bienestar espiritual; Satisfacción de vida.

\section{Introduction}

Nowadays, Technical and Vocational Education and Training (TVET) and research on TVET are one of the main principles of the comprehensive development, especially the implementation of the macro-employment policies in Iran. Technical and vocational schools are proud to play a crucial role in labor supply and employment growth and also they play an important role in the elimination of deprivation and the self-employment culture. The officials of higher education institutions have to pay enough attention to the students' academic emotions which can be considered as one of the most important issues in this regard because the lack of academic emotions not only affects the destiny of students, but also damages their mental health and thus they fail in their professional life and personal life. The more students evaluate the learning environment positively and satisfactorily, and have the positive academic emotions, the smoother their education path will be (Kadivar \& Kavousian, 2012). Pekrun et al (2002) define emotions as a set of the interrelated psychological processes that including feelings, cognition, motivational and psychological factors and psychological reactions. They believe that the academic emotions are defined as emotions which are directly linked to the achievement activities or achievement outcomes, and include subscales such as enjoyment, pride, anger, anxiety, shame, hopelessness, and boredom. According to this definition, the emotions related to the achievement activities are also considered to be achievement emotions. Pekrun et al (2009) identify learning- centered 
emotions and achievement emotions and define them as "academic emotions". Academic emotions are directly related to achievement activities or achievement outcomes. According to Pekrun 's model, the effect of emotions on learning and achievement is created by some cognitive and motivational mediating mechanisms, which include students' motivation, learning strategies, cognitive resources, and self-regulation. The academic settings, students often experience full range of the academic emotions. Specifically, the positive academic emotions such as enjoyment, hope, and pride are positively correlated with students' self-regulated learning and achievement and also their negative academic emotions such as anxiety, shame, hopelessness, and boredom are directly linked to the failure.

One of the variables associated with positive emotions is the spiritual well-being. Gomz \& Fisher (2003) define spiritual well-being as a state of health reflecting the positive feelings, behaviors, and cognitions of relationships with oneself, others, the transcendent and nature, which in turn provide a person with a sense of identity, wholeness, satisfaction, enjoyment, contentment, beauty, love, respect, positive attitudes, inner peace, harmony, purpose and direction of life(as cited by Masoumi, 2015). Hatgelman et al. (1985), as cited by Masoumi (2015), define the spiritual well-being as a sense of harmony and connection with oneself, others, the transcendent and nature that is achieved by a dynamic and cohesive growth process and can lead to understanding the ultimate goal of life and meaning in life. When spiritual wellbeing is endangered in a person, he / she would suffer from the mental disorders such as depression and loss of meaning in life, which can make it difficult to adapt to life, especially eternal life (Dastgheibet al., 2014). Spiritual well-being is important, especially for students searching for purpose or meaning in life, because it increase their decision-making power, inner peace, selfawareness and socio-moral adaptation (Asadi, Aghaei \& Atashpour, 2011). Another factor influencing academic emotions is life satisfaction. Life satisfaction refers to a person's feeling about performance and living conditions. It is a cognitive process of judgment based on a comparison of one's perceived life circumstance with a self-imposed standard or set of standards is presumably is made(Diner et al., 1985). Life satisfaction involves the positive attitude toward one's life and is in fact the feeling of happiness (Diner et al., 1985). If students enjoy a high level of the spiritual well-being and life satisfaction, the learning environment and academic activities may meet their needs and improve their psychological well-being, resulting in higher academic emotions. Cocordada (2016) conducted a study entitled "Achievement emotions and performance among university students". The results showed that there is a significant positive correlation between the positive emotions such as enjoyment, hope, pride and school performance and also a significant negative correlation is observed between the negative emotions such as hopelessness and boredom and school performance. Also, no significant association was found between other emotions (e.g., anxiety, shame) and school performance. In their study, Pegizeto et al (2015) demonstrated that there is a significant relationship between the positive emotions such as enjoyment, hope and pride and students' midterm exam scores. In other words, there is a significant negative correlation between negative emotions (such as anger, anxiety, shame, hopelessness and boredom) and midterm exam scores. In their study, Mirshekari et al (2020) showed that there is a significant inverse relationship between life satisfaction and anger in the school environment and life satisfaction can predict anger in the school environment. The results of several qualitative studies showed that students experience the different types of emotions in the learning settings, which may appear periodically and in different frequencies depending on the learning situation. A diversity of emotions should be considered in order to gain a deeper understanding of students' emotional lives. Also, in their study, Hajitabar et al. (2019) showed that having purpose or meaning and in life can guarantee students' adaptation to the school. Moreover, in their study, Hashemi and Jokar (2011) demonstrated that enhancing the level of spirituality can be led to an increase in people's resilience.People who have high spiritual intelligence can have a holistic view of life and by enjoying the moral virtues, they have a greater ability to solve problems and adapt to their working conditions, and also life satisfaction can bring inner peace into one's life. Given the fact that many students face a lot of problems and challenges 
in the learning setting on a daily basis, it is expected that both the spiritual well-being and life satisfaction can play an important role in predicting and improving students' academic emotions. Therefore, the aim of this study was to predict the academic emotions based on spiritual wellbeing and life satisfaction in students of Shahrekord Girls' Technical and Vocational School.

\section{Materials \& Methods}

\section{Population, sample and sampling method}

In this study, the sample size was determined using Krejcie \& Morgan (1970) table. 278 out of the sample of 983 people were selected by the stratified random sampling. The data were collected using the following instruments.

\section{Pakran Academic Emotions Questionnaire}

The achievement emotions questionnaire (AEQ) was developed by Pekrun et al. (2005). The AEQ contains 43 items and seven subscales (such as enjoyment (5 items: 1,9 14,18, 26), pride(items: $7,17,23,30,37)$, anxiety (5 items: $2,12,27,33,42)$ shame ( 8 items: $4,11,15,20,24,29,35,41)$, anger (4 items: 16, 21, 31, 36), hopelessness (4 items: 5, 7, 25, 32) boredom (11 items: $3,6,10,13,19,22,28,34,38,40,43$ ) (Kadivar et al., 2012. This scale is suitable for measuring academic emotions. Each item is rated on a five-point Likert scale (examples: "I enjoy being in class"). In this study, the the Cronbach's alpha for this scale was estimated to be above 0.7 and the questionnaire's reliability using Cronbach's alpha indicated 0.92 .

\section{The spiritual well-being questionnaire (SWBQ) (Paloutzian and Ellison, 1983)}

In the spiritual well-being questionnaire (SWBQ), each positive item is rated on a five-point Likert scale(e.g., $1=$ Strongly Disagree, $2=$ Disagree, $3=$ Neutral, $4=$ Agree, $5=$ Strongly Agree). However, some of the items $(1,2,5,6,9,12,13,16,18)$ are scored reversely(e.g., $5=$ Strongly Disagree, $4=$ Disagree, $3=$ Neutral, $2=$ Agree, $1=$ Strongly Agree). There is no grading scale for religious well-being (RWB) subscale and existential well-being EWB subscale, and judgments are made based on the score obtained. Higher scores represent higher religious and existential well-being. The SWB score is calculated by summing up RWB and EWB scores, ranging from 20-120. The RWB is divided into three levels: low (20 to 40), moderate (41 to 99), and high (100 to 120) (Mohammadi \& Tajvidi, 1390). In a study conducted by Abbasi (2005) on 283 nursing students studying in the universities of Iran, Tehran, and Shahid Beheshti, the reliability of this scale was reported to be $\mathrm{R}=0.82$. In the present study, the questionnaire's reliability using Cronbach's alpha indicated 0.89 .

\section{The Satisfaction With Life Scale (SWLS)}

Life satisfaction is a cognitive process of judgment based on a comparison of one's perceived life circumstance with a self-imposed standard or set of standards is presumably is made(Diner et al., 1985). Life Satisfaction is not individuals' satisfaction with specific areas of life. Life Satisfaction is a key indicator of subjective well-being and represents its cognitive component, measuring individuals' judgment of their own lives (Bastuga \& Dumana; 2010, Pavot \& Diener, 1993; Garcia \& Rozenberg \&Siddiqui,2010). The Satisfaction With Life Scale (SWLS)was developed by Diener et al. (1985). This scale contains 5 items and each item and each item is rated on a 7 -point Likert-type scale (Wu et al., 2009). Scores range from 5 to 35 (31-35 = Extremely Satisfied; 26$30=$ Satisfied; $21-25=$ Slightly Satisfied; $20=$ Neutral; $15-19=$ Slightly Dissatisfied; $10-14=$ Dissatisfied; 5-9= Extremely Dissatisfied). Higher scores reflect greater life satisfaction. Testretest reliability of the original version of the questionnaire was 0.82 and the questionnaire's reliability using Cronbach's alpha indicated 0.87(Diner et al., 1985). Test-retest reliability of 
Persian version of the questionnaire was 0.69 and the reliability of the SWLS using Cronbach's alpha indicated 0.83 . Construct validity of this scale was acceptable as compared with the other two questionnaires (Bayani et al, 2007). In another study, test-retest reliability of this scale was 0.90 and the reliability of the SWLS using Cronbach's alpha indicated 0.85 (Tagharobi et al, 2012). In the present study, the reliability of the SWLS using Cronbach's alpha indicated 0.85. Of this total of 328 questionnaires, 68 were incomplete or inaccurately filled out. Incomplete questionnaires were excluded from the study

\section{Results}

Multivariate regression analysis was used to test the research hypotheses. The use of the regression model requires that several assumptions.Statistical assumptions were as follows.

\section{The assumption of normal distribution in the data}

The Kolmogorov-Smirnov test and the Shapiro-Wilk test was used to assess the normal distribution of the study variables

Table 1. The Kolmogorov-Smirnov test and the Shapiro-Wilk test for the assessment of the normal distribution of the study variables

\begin{tabular}{ccccccc}
\hline & \multicolumn{2}{c}{ Kolmogorov-Smirnov test } & \multicolumn{3}{c}{ Shapiro-Wilk test } \\
\cline { 2 - 7 } & Statistic & $\begin{array}{c}\text { Degree of } \\
\text { freedom }\end{array}$ & P value & Statistic & $\begin{array}{c}\text { Degree of } \\
\text { freedom }\end{array}$ & P value \\
$\begin{array}{c}\text { Spiritual } \\
\text { Well-being }\end{array}$ & 0.079 & 210 & 0.003 & 0.983 & 210 & 0.014 \\
$\begin{array}{c}\text { Life } \\
\text { Satisfaction }\end{array}$ & 0.079 & 210 & 0.003 & 0.982 & 210 & 0.009 \\
Enjoyment & 0.082 & 210 & 0.002 & 0.981 & 210 & 0.007 \\
Pride & 0.070 & 210 & 0.013 & 0.978 & 210 & 0.002 \\
Anxiety & 0.103 & 210 & 0.0001 & 0.981 & 210 & 0.007 \\
Shame & 0.077 & 210 & 0.004 & 0.973 & 210 & 0.001 \\
\hline Anger & 0.077 & 210 & 0.004 & 0.973 & 210 & 0.001 \\
Hopelessness & 0.097 & 210 & 0.0001 & 0.971 & 210 & 0.0001 \\
Boredom & 0.092 & 210 & 0.0001 & 0.988 & 210 & 0.066 \\
\hline
\end{tabular}

As shown in Table 1, the Kolmogorov-Smirnov test and the Shapiro-Wilk test had a statistically significant value for each variable, indicating that the study variables were not normally distributed. To solve this problem, the natural logarithm of the variables should be used and all variables have been transformed into their natural logarithms. The Durbin-Watson test was used to assess the assumption of independence of predictor variables. Its value was equal to 2.084 , ranging from 1.5 to 2.5 , and indicated the independence of predictor variables. The tolerance test was used to assess The assumption of the collinearity. Among the dimensions of academic emotions, only boredom and anxiety had this condition and the rest did not.

Table 2. Model Summary of predicting the academic emotions (enjoyment) based on spiritual well-being and life satisfaction in students of Girls' Technical and Vocational School

\begin{tabular}{|c|c|c|c|c|c|c|c|c|c|}
\hline \multirow[b]{2}{*}{ Model } & \multirow[b]{2}{*}{$\mathbf{R}$} & \multirow[b]{2}{*}{$\mathbf{R}^{2}$} & \multirow[b]{2}{*}{$\begin{array}{l}\text { Adjusted } \\
\qquad \mathbf{R}^{2}\end{array}$} & \multirow{2}{*}{$\begin{array}{c}\text { The standard } \\
\text { error of } \\
\text { estimate (SEE) }\end{array}$} & \multicolumn{5}{|c|}{ Change statistics } \\
\hline & & & & & $\underset{\text { change }}{\mathbf{R}^{2}}$ & $\mathbf{F}$ & df1 & df2 & Sig \\
\hline 1 & 0.264 & 0.07 & 0.065 & 0.28 & 0.070 & 15.640 & 1 & 208 & 0.0001 \\
\hline
\end{tabular}

As shown in Table 2, life satisfaction could predict $7 \%$ of academic emotions(enjoyment) in students of Girls' Technical and Vocational School, and spiritual well-being did not predict the 
academic emotions (enjoyment) in these students and could not be considered as a predictive model.

Table 3. Analysis of variance (ANOVA) for predicting the academic emotions (enjoyment) based on spiritual well-being and life satisfaction in students of Girls' Technical and Vocational School

\begin{tabular}{ccccccc}
\hline Model & & $\begin{array}{c}\text { Total sum } \\
\text { of squares }\end{array}$ & $\begin{array}{c}\text { Degree of } \\
\text { freedom }\end{array}$ & $\begin{array}{c}\text { Mean } \\
\text { squares }\end{array}$ & F & sig \\
\hline \multirow{2}{*}{$\mathbf{1}$} & Regression & 0.682 & 1 & 0.682 & & \\
& $\begin{array}{c}\text { Residue } \\
\text { Total }\end{array}$ & 9.065 & 208 & 0.044 & 15.64 & 0.0001 \\
& 9.746 & 209 & & & \\
\hline
\end{tabular}

It could be seen from this table that value of R2 was statistically significant for the academic emotions (enjoyment) in the students of Girls' Technical and Vocational School.

Table 4. Coefficients of prediction for the academic emotions (enjoyment) based on spiritual well-being and life satisfaction in students of Girls' Technical and Vocational School

\begin{tabular}{|c|c|c|c|c|c|c|}
\hline \multirow[b]{2}{*}{ Model } & & \multicolumn{2}{|c|}{$\begin{array}{c}\text { Unstandardized } \\
\text { coefficients }\end{array}$} & \multirow{2}{*}{$\begin{array}{c}\begin{array}{c}\text { Standardized } \\
\text { coefficient }\end{array} \\
\text { Beta }\end{array}$} & \multirow[b]{2}{*}{$\mathbf{T}$} & \multirow[b]{2}{*}{ Sig } \\
\hline & & B & $\begin{array}{c}\text { The } \\
\text { standar } \\
\text { d error }\end{array}$ & & & \\
\hline & constant & 2.385 & 0.111 & & 21.53 & 0.0001 \\
\hline 1 & $\begin{array}{c}\text { life } \\
\text { satisfaction }\end{array}$ & 0.162 & 0.041 & 0.264 & 3.95 & 0.0001 \\
\hline
\end{tabular}

As shown in Table 4, the beta coefficient of life satisfaction was equal to 0.264 , indicating that with increasing the life satisfaction $(\beta=0.264)$ in students of Girls' Technical and Vocational School, their academic emotions (enjoyment) increased by one unit.

Table 5. Model Summary of predicting the academic emotions (pride) based on spiritual wellbeing and life satisfaction in students of Girls' Technical and Vocational School

\begin{tabular}{|c|c|c|c|c|c|c|c|c|c|}
\hline \multirow[b]{2}{*}{ Model } & \multirow[b]{2}{*}{$\mathbf{R}$} & \multirow[b]{2}{*}{$\mathbf{R}^{2}$} & \multirow[b]{2}{*}{$\begin{array}{l}\text { Adjusted } \\
\qquad \mathbf{R}^{2}\end{array}$} & \multirow{2}{*}{$\begin{array}{l}\text { The standard } \\
\text { error of } \\
\text { estimate (SEE) }\end{array}$} & \multicolumn{5}{|c|}{ Change statistics } \\
\hline & & & & & $\begin{array}{c}\mathbf{R}^{2} \\
\text { change }\end{array}$ & $\mathbf{F}$ & df1 & df2 & Sig \\
\hline 1 & 0.204 & 0.042 & 0.037 & 0.23 & 0.042 & 9.041 & 1 & 208 & 0.0001 \\
\hline
\end{tabular}

As shown in Table 5, spiritual well-being could predict $4.2 \%$ of academic emotions(pride) in students of Girls' Technical and Vocational School, and life satisfaction did not predict the academic emotions(pride) in these students and could not be considered as a predictive model.

Table 6. ANOVA for predicting the academic emotions (pride) based on spiritual well-being and life satisfaction in students of Girls' Technical and Vocational School

\begin{tabular}{ccccccc}
\hline Model & & $\begin{array}{c}\text { Total sum of } \\
\text { squares }\end{array}$ & $\begin{array}{c}\text { Degree of } \\
\text { freedom }\end{array}$ & $\begin{array}{c}\text { Mean } \\
\text { squares }\end{array}$ & F & sig \\
\hline \multirow{2}{*}{$\mathbf{1}$} & Regression & 0.482 & 1 & 0.485 & & \\
& Residue & 11.15 & 208 & 0.054 & 9.041 & 0.003 \\
& Total & 11.64 & 209 & & & \\
\hline
\end{tabular}

It could be seen from this table that value of R2 was statistically significant for the academic emotions (pride) in the students of Girls' Technical and Vocational School. 
Table 7. Coefficients of prediction for the academic emotions (pride) based on spiritual wellbeing and life satisfaction in students of Girls' Technical and Vocational School

\begin{tabular}{|c|c|c|c|c|c|c|}
\hline \multirow[b]{2}{*}{ Model } & & \multicolumn{2}{|c|}{$\begin{array}{c}\text { Unstandardized } \\
\text { coefficients } \\
\end{array}$} & \multirow{2}{*}{$\begin{array}{c}\begin{array}{c}\text { Standardized } \\
\text { coefficient }\end{array} \\
\text { Beta }\end{array}$} & \multirow[b]{2}{*}{$\mathbf{T}$} & \multirow[b]{2}{*}{ Sig } \\
\hline & & B & $\begin{array}{c}\text { The } \\
\text { standar } \\
\text { d error }\end{array}$ & & & \\
\hline \multirow[b]{2}{*}{1} & constant & 1.360 & 0.503 & & 2.706 & 0.0001 \\
\hline & $\begin{array}{c}\text { life } \\
\text { satisfaction }\end{array}$ & 0.365 & 0.122 & 0.204 & 3.007 & 0.0001 \\
\hline
\end{tabular}

As indicated in Table 7, the beta coefficient of spiritual well-being was equal to 0.204 , indicating that with increasing the spiritual well-being $(\beta=0.204)$ in students of Girls' Technical and Vocational School, their academic emotions (pride) increased by one unit.

Table 8. Model Summary of predicting the academic emotions (anxiety) based on spiritual wellbeing and life satisfaction in students of Girls' Technical and Vocational School

\begin{tabular}{|c|c|c|c|c|c|c|c|c|c|}
\hline \multirow[b]{2}{*}{ Model } & \multirow[b]{2}{*}{$\mathbf{R}$} & \multirow[b]{2}{*}{$\mathbf{R}^{2}$} & \multirow[b]{2}{*}{$\begin{array}{l}\text { Adjusted } \\
\qquad \mathbf{R}^{2}\end{array}$} & \multirow{2}{*}{$\begin{array}{l}\text { The standard } \\
\text { error of } \\
\text { estimate (SEE) }\end{array}$} & \multicolumn{5}{|c|}{ Change statistics } \\
\hline & & & & & $\underset{\text { change }}{\mathbf{R}^{2}}$ & $\mathbf{F}$ & df1 & df2 & Sig \\
\hline 1 & 0.240 & 0.058 & 0.053 & 0.35 & 0.058 & 12.699 & 1 & 208 & 0.0001 \\
\hline
\end{tabular}

As indicated in Table 8, life satisfaction could predict $4.2 \%$ of academic emotions(anxiety) in students of Girls' Technical and Vocational School, and spiritual well-being did not predict the academic emotions(anxiety) in these students and could not be considered as a predictive model.

Table 9. ANOVA for predicting the academic emotions (anxiety) based on spiritual well-being and life satisfaction in students of Girls' Technical and Vocational School

\begin{tabular}{ccccccc}
\hline Model & & $\begin{array}{c}\text { Total sum } \\
\text { of squares }\end{array}$ & $\begin{array}{c}\text { Degree of } \\
\text { freedom }\end{array}$ & $\begin{array}{c}\text { Mean } \\
\text { squares }\end{array}$ & F & sig \\
\hline \multirow{2}{*}{1} & Regression & 1.588 & 1 & 1.588 & & \\
& Residue & 26.004 & 208 & 0.125 & 12.699 & 0.003 \\
& Total & 27.59 & 209 & & & \\
\hline
\end{tabular}

It could be seen from this table that value of R2 was statistically significant for the academic emotions (anxiety) in the students of Girls' Technical and Vocational School.

Table 10. Coefficients of prediction for the academic emotions (anxiety) based on spiritual wellbeing and life satisfaction in students of Girls' Technical and Vocational School

\begin{tabular}{|c|c|c|c|c|c|c|}
\hline \multirow[b]{2}{*}{ Model } & & \multicolumn{2}{|c|}{$\begin{array}{c}\text { Unstandardized } \\
\text { coefficients }\end{array}$} & \multirow{2}{*}{$\begin{array}{c}\begin{array}{c}\text { Standardized } \\
\text { coefficient }\end{array} \\
\text { Beta }\end{array}$} & \multirow[b]{2}{*}{$\mathbf{T}$} & \multirow[b]{2}{*}{ Sig } \\
\hline & & B & $\begin{array}{c}\text { The } \\
\text { standar } \\
\text { d error }\end{array}$ & & & \\
\hline & constant & 3.217 & 0.188 & & 17.15 & 0.0001 \\
\hline 1 & $\begin{array}{c}\text { life } \\
\text { satisfaction }\end{array}$ & $\begin{array}{c}- \\
0.248\end{array}$ & 0.070 & -0.240 & -3.56 & 0.0001 \\
\hline
\end{tabular}

As shown in Table 10, the beta coefficient of life satisfaction was equal to -0.240 , indicating that with increasing the life satisfaction $(\beta=0.240)$ in students of Girls' Technical and Vocational School, their academic emotions (anxiety) decreased by one unit. 
Table 11. Model Summary of predicting the academic emotions (shame) based on spiritual wellbeing and life satisfaction in students of Girls' Technical and Vocational School

\begin{tabular}{ccccccccccc}
\hline Model & $\mathbf{R}$ & $\mathbf{R}^{2}$ & $\begin{array}{c}\text { Adjusted } \\
\mathbf{R}^{\mathbf{2}}\end{array}$ & $\begin{array}{c}\text { The standard } \\
\text { error of estimate }\end{array}$ & \multicolumn{4}{c}{ Change statistics } \\
\cline { 8 - 11 } & & & $\begin{array}{c}\mathbf{R}^{\mathbf{2}} \\
\text { change }\end{array}$ & $\mathbf{F}$ & $\mathbf{d f 1}$ & $\mathbf{d f 2}$ & Sig \\
\hline & 0.308 & 0.043 & 0.039 & 0.35 & 0.043 & 9.446 & 1 & 308 & 0.002 \\
\hline
\end{tabular}

As shown in Table 11, life satisfaction could predict $4.3 \%$ of academic emotions(shame) in students of Girls' Technical and Vocational School, and spiritual well-being did not predict the academic emotions (shame) in these students and could not be considered as a predictive model.

Table 12. ANOVA for predicting the academic emotions (shame) based on spiritual well-being and life satisfaction in students of Girls' Technical and Vocational School

\begin{tabular}{ccccccc}
\hline Model & & $\begin{array}{c}\text { Total sum of } \\
\text { squares }\end{array}$ & $\begin{array}{c}\text { Degree of } \\
\text { freedom }\end{array}$ & $\begin{array}{c}\text { Mean } \\
\text { squares }\end{array}$ & F & sig \\
\hline \multirow{2}{*}{$\mathbf{1}$} & Regression & 1.221 & 1 & 1.221 & & \\
& Residue & 26.87 & 208 & 0.129 & 9.446 & 0.002 \\
& Total & 38.09 & 209 & & & \\
\hline
\end{tabular}

It could be seen from this table that value of R2 was statistically significant for the academic emotions (shame) in the students of Girls' Technical and Vocational School.

Table 13. Coefficients of prediction for the academic emotions (shame) based on spiritual wellbeing and life satisfaction in students of Girls' Technical and Vocational School

\begin{tabular}{ccccccc}
\hline \multirow{2}{*}{ Model } & & \multicolumn{2}{c}{$\begin{array}{c}\text { Unstandardized } \\
\text { coefficients }\end{array}$} & $\begin{array}{c}\text { Standardized } \\
\text { coefficient }\end{array}$ & \multirow{2}{*}{ T } & Sig \\
\cline { 3 - 5 } & & B & $\begin{array}{c}\text { The } \\
\text { standar } \\
\text { d error }\end{array}$ & Beta & & \\
\cline { 3 - 5 } $\mathbf{1}$ & constant & 3.462 & 0.191 & & 18.160 & 0.0001 \\
\hline
\end{tabular}

As indicated in Table 13, the beta coefficient of life satisfaction was equal to -0.208 , demonstrating that with increasing the life satisfaction $(\beta=0.208)$ in students of Girls' Technical and Vocational School, their academic emotions (shame) decreased by one unit.

Table 14. Model Summary of predicting the academic emotions (anger) based on spiritual wellbeing and life satisfaction in students of Girls' Technical and Vocational School

\begin{tabular}{|c|c|c|c|c|c|c|c|c|c|}
\hline \multirow[b]{2}{*}{ Model } & \multirow[b]{2}{*}{$\mathbf{R}$} & \multirow[b]{2}{*}{$\mathbf{R}^{2}$} & \multirow[b]{2}{*}{$\begin{array}{c}\text { Adjusted } \\
\qquad \mathbf{R}^{2}\end{array}$} & \multirow{2}{*}{$\begin{array}{l}\text { The standard } \\
\text { error of estimate } \\
\text { (SEE) }\end{array}$} & \multicolumn{5}{|c|}{ Change statistics } \\
\hline & & & & & $\begin{array}{c}\mathbf{R}^{2} \\
\text { change }\end{array}$ & $\mathbf{F}$ & df1 & df2 & Sig \\
\hline 1 & 0.208 & 0.043 & 0.039 & 0.35 & 0.043 & 9.446 & 1 & 308 & 0.002 \\
\hline
\end{tabular}

It could be seen from this table that life satisfaction could predict $4.3 \%$ of academic emotions(anger) in students of Girls' Technical and Vocational School, and spiritual well-being did not predict the academic emotions(anger) in these students and could not be regarded as a predictive model.

Table 15. ANOVA for predicting the academic emotions (anger) based on spiritual well-being and life satisfaction in students of Girls' Technical and Vocational School 


\begin{tabular}{ccccccc}
\hline Model & Total sum of & $\begin{array}{c}\text { Degree of } \\
\text { squares }\end{array}$ & $\begin{array}{c}\text { Mean } \\
\text { freedom }\end{array}$ & squares & F & sig \\
\hline \multirow{2}{*}{$\mathbf{1}$} & Regression & 1.221 & 1 & 1.221 & & \\
& Residue & 26.87 & 208 & 0.129 & 9.446 & 0.002 \\
& Total & 38.09 & 209 & & & \\
\hline
\end{tabular}

As indicated in Table 15, value of R2 was statistically significant for the academic emotions (anger) in the students of Girls' Technical and Vocational School.

Table 16. Coefficients of prediction for the academic emotions (anger) based on spiritual wellbeing and life satisfaction in students of Girls' Technical and Vocational School

\begin{tabular}{|c|c|c|c|c|c|c|}
\hline \multirow[b]{2}{*}{ Model } & & \multicolumn{2}{|c|}{$\begin{array}{c}\text { Unstandardized } \\
\text { coefficients }\end{array}$} & \multirow{2}{*}{$\begin{array}{c}\begin{array}{c}\text { Standardized } \\
\text { coefficient }\end{array} \\
\text { Beta }\end{array}$} & \multirow[b]{2}{*}{$\mathbf{T}$} & \multirow[b]{2}{*}{ Sig } \\
\hline & & B & $\begin{array}{c}\text { The } \\
\text { standar } \\
\text { d error }\end{array}$ & & & \\
\hline \multirow{2}{*}{1} & constant & 3.462 & 0.191 & & 18.160 & 0.0001 \\
\hline & life satisfaction & -0.217 & 0.071 & -0.208 & -3.073 & 0.0001 \\
\hline
\end{tabular}

As shown in Table 16, the beta coefficient of life satisfaction was equal to -0.208 , suggesting that with increasing the life satisfaction $(\beta=0.208)$ in students of Girls' Technical and Vocational School, their academic emotions (anger) decreased by one unit.

Table 17. Model Summary of predicting the academic emotions (hopelessness) based on spiritual well-being and life satisfaction in students of Girls' Technical and Vocational School

\begin{tabular}{ccccccccccc}
\hline Model & $\mathbf{R}$ & $\mathbf{R}^{2}$ & $\begin{array}{c}\text { Adjusted } \\
\mathbf{R}^{\mathbf{2}}\end{array}$ & $\begin{array}{c}\text { The standard } \\
\text { error of } \\
\text { estimate (SEE) }\end{array}$ & \multicolumn{5}{c}{ Change statistics } \\
\cline { 8 - 11 } & & & $\mathbf{R}^{2}$ & $\mathbf{F}$ & $\mathbf{d f 1}$ & $\mathbf{d f 2}$ & Sig \\
\hline & 0.308 & 0.095 & 0.091 & 0.38 & 0.095 & 21.81 & 1 & 208 & 0.0001 \\
\hline
\end{tabular}

It could be seen from this table that life satisfaction could predict $3.8 \%$ of academic emotions(anger) in students of Girls' Technical and Vocational School, and spiritual well-being did not predict the academic emotions (hopelessness) in these students and could not be viewed as a predictive model.

Table 18. ANOVA for predicting the academic emotions (hopelessness) based on spiritual wellbeing and life satisfaction in students of Girls' Technical and Vocational School

\begin{tabular}{ccccccc}
\hline Model & & $\begin{array}{c}\text { Total sum } \\
\text { of squares }\end{array}$ & $\begin{array}{c}\text { Degree of } \\
\text { freedom }\end{array}$ & $\begin{array}{c}\text { Mean } \\
\text { squares }\end{array}$ & F & sig \\
\hline \multirow{2}{*}{$\mathbf{1}$} & Regression & 3.308 & 1 & 3.308 & & \\
& $\begin{array}{c}\text { Residue } \\
\text { Total }\end{array}$ & 31.54 & 208 & 0.152 & 21.816 & 0.0001 \\
& & 34.84 & 209 & & & \\
\hline
\end{tabular}

As indicated in Table 18, value of R2 was statistically significant for the academic emotions (hopelessness) in the students of Girls' Technical and Vocational School.

Table 19. Coefficients of prediction for the academic emotions (hopelessness) based on spiritual well-being and life satisfaction in students of Girls' Technical and Vocational School 


\begin{tabular}{|c|c|c|c|c|c|c|}
\hline \multirow[b]{2}{*}{ Model } & & \multicolumn{2}{|c|}{$\begin{array}{c}\text { Unstandardized } \\
\text { coefficients }\end{array}$} & \multirow{2}{*}{$\begin{array}{c}\begin{array}{c}\text { Standardized } \\
\text { coefficient }\end{array} \\
\text { Beta }\end{array}$} & \multirow[b]{2}{*}{$\mathbf{T}$} & \multirow[b]{2}{*}{ Sig } \\
\hline & & B & $\begin{array}{c}\text { The } \\
\text { standar } \\
\text { d error }\end{array}$ & & & \\
\hline \multirow{2}{*}{1} & constant & 3.212 & 0.207 & & 15.551 & 0.0001 \\
\hline & life satisfaction & -0.358 & 0.077 & -0.308 & -4.671 & 0.0001 \\
\hline
\end{tabular}

It could be seen from this table that the beta coefficient of life satisfaction was equal to 0.308 , suggesting that with increasing the life satisfaction $(\beta=0.308)$ in students of Girls' Technical and Vocational School, their academic emotions (hopelessness) reduced by one unit.

Table 20. Model Summary of predicting the academic emotions (boredom) based on spiritual well-being and life satisfaction in students of Girls' Technical and Vocational School

\begin{tabular}{|c|c|c|c|c|c|c|c|c|c|}
\hline \multirow[b]{2}{*}{ Model } & \multirow[b]{2}{*}{$\mathbf{R}$} & \multirow[b]{2}{*}{$\mathbf{R}^{2}$} & \multirow[b]{2}{*}{$\begin{array}{l}\text { Adjusted } \\
\qquad \mathbf{R}^{2}\end{array}$} & \multirow{2}{*}{$\begin{array}{l}\text { The standard } \\
\text { error of } \\
\text { estimate (SEE) }\end{array}$} & \multicolumn{5}{|c|}{ Change statistics } \\
\hline & & & & & $\begin{array}{c}\mathbf{R}^{2} \\
\text { change }\end{array}$ & $\mathbf{F}$ & df1 & df2 & Sig \\
\hline 1 & 0.407 & 0.165 & 0.161 & 0.26 & 0.165 & 41.18 & 1 & 208 & 0.0001 \\
\hline
\end{tabular}

As shown in table 20, life satisfaction could predict $4.3 \%$ of academic emotions(boredom) in students of Girls' Technical and Vocational School, and spiritual well-being did not predict the academic emotions(boredom) in these students and could not be viewed as a predictive model.

Table 21. ANOVA for predicting the academic emotions (boredom) based on spiritual well-being and life satisfaction in students of Girls' Technical and Vocational School

\begin{tabular}{ccccccc}
\hline Model & & $\begin{array}{c}\text { Total sum } \\
\text { of squares }\end{array}$ & $\begin{array}{c}\text { Degree of } \\
\text { freedom }\end{array}$ & $\begin{array}{c}\text { Mean } \\
\text { squares }\end{array}$ & F & sig \\
\hline \multirow{2}{*}{$\mathbf{1}$} & Regression & 2.967 & 1 & 2.967 & & \\
& Residue & 14.98 & 208 & 0.072 & 41.18 & 0.0001 \\
& Total & 17.95 & 209 & & & \\
\hline
\end{tabular}

It could be seen from this table that value of R2 was statistically significant for the academic emotions (boredom) in the students of Girls' Technical and Vocational School.

Table 22. Coefficients of prediction for the academic emotions (boredom) based on spiritual wellbeing and life satisfaction in students of Girls' Technical and Vocational School

\begin{tabular}{|c|c|c|c|c|c|c|}
\hline \multirow[b]{2}{*}{ Model } & & \multicolumn{2}{|c|}{$\begin{array}{c}\text { Unstandardized } \\
\text { coefficients }\end{array}$} & $\begin{array}{c}\text { Standardized } \\
\text { coefficient }\end{array}$ & \multirow[b]{2}{*}{$\mathbf{T}$} & \multirow[b]{2}{*}{ Sig } \\
\hline & & B & $\begin{array}{c}\text { The } \\
\text { standar } \\
\text { d error }\end{array}$ & Beta & & \\
\hline & constant & 4.408 & 0.142 & & 30.962 & 0.0001 \\
\hline 1 & life satisfaction & -0.339 & 0.053 & -0.407 & -6.418 & 0.0001 \\
\hline
\end{tabular}

As shown in Table 22, the beta coefficient of life satisfaction was equal to -0.407 , indicating that with increasing the life satisfaction $(\beta=0.407)$ in students of Girls' Technical and Vocational School, their academic emotions (boredom) reduced by one unit.

\section{Discussion And Conclusion}

The results of the present study demonstrated that spiritual well-being could predict academic emotions (pride) in students of Girls' Technical and Vocational School, and life satisfaction can 
predict academic emotions such as enjoyment, anxiety, shame, anger and hopelessness in these students, but no significant association was found between life satisfaction and academic emotions (pride). Hatgelman et al. (1985), define the spiritual well-being as a sense of harmony and connection with oneself, others, the transcendent and nature that is achieved by a dynamic and cohesive growth process and can lead to understanding the ultimate goal of life and meaning in life. Gomz \& Fisher (2003) define spiritual well-being as a state of health reflecting the positive feelings, behaviors, and cognitions of relationships with oneself, others, the transcendent and nature, which in turn provide a person with a sense of identity, wholeness, satisfaction, enjoyment, contentment, beauty, love, respect, positive attitudes, inner peace, harmony, purpose and direction of life. Given the importance of spiritual well-being, it can increases the academic emotions (pride) in university students. But the fact that spiritual well-being did not predict academic emotions such as hopelessness, shame, anxiety, anger, and boredom can be explained as follows. Since spiritual well-being includes religious well-being, i.e., "communication with God " and existential well-being, i.e., "how to communicate with oneself, society and the environment ", which is concerned with social adjustment; however, some questions do not seem to be clear enough to students, especially those containing specific concepts such as " Unimaginable God " or "philosophy of existence", Where did I come from, Where am I going? Finally, students have been confused about how to relate these concepts to academic emotions. On the one hand, economic and social problems or issues, as well as the high cost of technical disciplines could affect the communication between the principle of spiritual beliefs and having a positive attitude in life confirmed by the answers" and academic emotions that the answers showed no significant relationship between them. On the other hand, the age of the students of technical is one year less than other students who have completed four years of high school, which can affect the accuracy of answering many questions in the questionnaire. The results of this study that with increasing students' life satisfaction $(\beta=0.26$ ), their academic emotions (enjoyment) decreased by one unit. Therefore, it seems that high financial ability and students' artistic and recreational view of some disciplines can affect our results. This study has some limitations which have to be pointed out.one of the limitations of this study is the lack of controlling the intervening variables and the lack of power to generalize the results to other populations. It is, therefore, recommended that in the planning of cultural and learning activities for university students, effective programs are considered for improving their spiritual well-being and academic emotions

\section{References}

- Abbasi, M., Amirian, L. (2018). The impact of spiritual well-being on psychological distress in patients with spinal cord injury: the mediating role of loneliness and hopelessness, Journal of Research on Religion and Health, 4 (4): 80-93.

- Asadi, M., Aghaei, A., Atashpour, H. (2011). The effects of life skills training on the high schools girl students' spiritual intelligence. Journal of woman and culture, 3 (9): 28.

- Bastuga, G., Dumana, S. (2010). Examining life satisfaction level depending on physical activity in Turkish and German societies. Journal of Procedia Social and Behavioral Sciences, 2: 4892-4895.

- Cocorada, E. (2016). Achievement emotions and performance among university students. Bulletin of the Transilvania University of Brasov Series Law, 9(1): 119.

- Dastgheib, Z., Gharlipour, Z., Ghobadi Dashdebi, K., Hosseini, F., Vafaee, R. (2013). Association between mental health and spiritual well-being among students in Shiraz University, the scientific journal of Faculty of Nursing and Midwifery, 24 (84): 52-59.

- Diener, E., et al. (1985). The Satisfaction with Life Scale. Journal of Personality Assessment, 49(1): 16-20.

- Garcia, D., Rosenberg, B., Siddiqui, A. (2010). The effect of temporal distance on adolescents' judgments of life satisfaction. Journal of Adolescence, 1-7 
- Hajitabar, M., Sheikhalaslami, A., Talebi, M., Barghi, I. (2019). Impact of the meaning in life on students' School Adjustment by mediating problem-focused coping and self-acceptance, Journal of Educational Psychology Studies, 16 (34): 59-76.

- Hashemi, L., Jokar, B. (2011). Investigating the relationship between spiritual excellence and resilience in university students, Journal of Psychology, 8 (13): 123-142.

- Kadivar, P., Farzad,V., Kavousian, J., Nikdel, F. (2009). Validating the Pekruns achievement emotions questionnaire. QuarterlyJournal of Educational Innovations,8(32):30.

- Masoumi, A (2015). Investigating the relationship between spiritual intelligence and spiritual well-being with academic achievement among the students of Tabriz University, The First International Congress of Psychology and Educational Sciences With Islamic Perspective, Gorgan.

- Mirshekar, Z., Mazaheri, M., Nikoofar, M. (2020). The role of life satisfaction and in predicting Anger in the school environment, Journal of Educational Psychology Studies, 17 (37): 63-84.

- Mohammadi, Sh. (2011). The Relationship between spiritual wellbeing and hopelessness and social skills in Beta-thalassemia major adolescents, Modern care journal, 4 (31): 116-124.

- Peixoto, F., Mata, L., Monteiro, V., \& Sanches, C., \& Pekrun, R. (2015). The Achievement Emotions Questionnaire: Validation for Pre-adolescent Students. European Journal of Developmental Psychology, 12 (4): 472-481.

- Pekrun, R., Elliot, A. J., Maier, M. A. (2009). Achievement goals and achievement emotions: Testing a model of their joint relations with academic performance. Journal of educational Psychology, 101(1): 115.

- Pekrun, R., Goetz, T., Titz, W., \& Perry, R. P. (2002). Academic emotions in students selfregulated learning and achievement: A program of quantitative and quantitative research. Educational Psychologist, 37: 91-106.

- Sujoodi, A., Masoomi Rad, R., Avardide, S., Abdi, F. (2015). Examining social factors affecting life satisfaction (Case study: students Payame Noor University, Shaft Branch, Rooyesh Journal, 8).

- Tagharobi, Z., Sharifi, Kh., Soki, Z. (2012). Subjective well-being in the students of Kashan Nursing \& Midwifery Faculty. Scientific Journal of Kashan School of Nursing and Midwifery, 20 (1): 431.

- Wu, C. H., Chen, L. H., and Tsai, Y. M. (2009). Longitudinal invariance analysis of the satisfaction with life scale. Personality and Individual Differences, 46(4): 396-4. 